University of South Florida

DIGITAL COMMONS

Digital Commons @ University of

@ UNIVERSITY OF SOUTH FLORIDA

South Florida

11-20-1984

\title{
Factors Influencing the Degree of Saturation of the Surface and Intermediate Waters of the North Pacific Ocean with Respect to Aragonite
}

\author{
Richard A. Feely \\ NOAA \\ Robert H. Byrne \\ University of South Florida, byrne@marine.usf.edu \\ Peter R. Betzer \\ University of South Florida, peter@stpetepartnership.org \\ James F. Gendron \\ NOAA \\ James G. Acker \\ University of South Florida \\ Follow this and additional works at: https://digitalcommons.usf.edu/msc_facpub \\ Part of the Marine Biology Commons
}

\section{Scholar Commons Citation \\ Feely, Richard A.; Byrne, Robert H.; Betzer, Peter R.; Gendron, James F.; and Acker, James G., "Factors Influencing the Degree of Saturation of the Surface and Intermediate Waters of the North Pacific Ocean with Respect to Aragonite" (1984). Marine Science Faculty Publications. 85. \\ https://digitalcommons.usf.edu/msc_facpub/85}

This Article is brought to you for free and open access by the College of Marine Science at Digital Commons @ University of South Florida. It has been accepted for inclusion in Marine Science Faculty Publications by an authorized administrator of Digital Commons @ University of South Florida. For more information, please contact digitalcommons@usf.edu. 


\title{
Factors Influencing the Degree of Saturation of the Surface and Intermediate Waters of the North Pacific Ocean With Respect to Aragonite
}

\begin{abstract}
Richard A. Feely, ${ }^{1}$ Robert H. Byrne, ${ }^{2}$ Peter R. Betzer, ${ }^{2}{ }^{\text {James }}$ F. Gendron, ${ }^{1}$ ANd James G. Acker ${ }^{2}$
New carbonate chemistry data obtained during a 1982 cruise have been combined with earlier GEOSECS and INDOPAC data to determine the degree of aragonite saturation of surface and intermediate waters of the North Pacific. Large gradients in saturation state occur in the region of the Subarctic Front in the north-south direction and across the Subtropical Gyre in the east-west direction. These gradients are primarily due to the extensive mixing that occurs in the intermediate waters of the western North Pacific. The major variations in saturation state were primarily related to the carbonate ion concentration, which, in turn, is primarily a function of mixing and biological processes. The present aragonite saturation depth at our northernmost station in the western North Pacific was calculated to be within $120 \mathrm{~m}$ of the surface. This result was directly corroborated by observations of aragonite dissolution under in vitro conditions. Our calculations show that one possible effect of fossil fuel-derived $\mathrm{CO}_{2}$ on the surface of the North Pacific will be a steady progression of undersaturation from the northern to southern and western areas, with the first sign of undersaturation possibly occurring as early as the second half of the next century.
\end{abstract}

\section{INTRODUCTION}

In recent years, concern about the progressive increase in the levels of fossil fuel-derived $\mathrm{CO}_{2}$ in the atmosphere has prompted several investigators to examine the potential impacts of increased levels of total $\mathrm{CO}_{2}$ on the degree of calcite and aragonite saturation in the oceanic mixed layer [Broecker et al., 1971; Fairhall, 1973; Zimen and Altenhein, 1973; Whitfield, 1974; Skirrow and Whitfield, 1975; Broecker et al., 1979]. The results of these investigations vary widely in their predictions of the fossil fuel $\mathrm{CO}_{2}$ inputs required to induce calcite and aragonite undersaturation. This is due partly to a lack of agreement about the exchange of fossil fuel $\mathrm{CO}_{2}$ across the air-sea interface and its subsequent penetration into the deeper layers of the ocean, and partly due to a lack of agreement about the salinity, temperature, and pressure effects on the stoichiometric solubility products for calcite and aragonite. Solubility product discrepancies are particuarly important for aragonite because some of the earlier solubility measurements did not take into account the long times required for equilibration [Morse et al., 1980]. To provide a comprehensive picture of aragonite saturation in the surface and intermediate waters of the North Pacific, we have combined the most recent aragonite solubility data for seawater temperatures and salinities [Mucci, 1983] with the GEOSECS, INDOPAC, and new National Oceanic and Atmospheric Administration (NOAA) total $\mathrm{CO}_{2}$ and alkalinity data (Figure 1). We have examined the major factors influencing the spatial variations in the degree of saturation and have used this information to discuss potential impacts of elevated levels of $\mathrm{CO}_{2}$ in surface waters. The North Pacific was chosen for this study because of the extensive data base that exists for this region and also because, with respect to aragonite, the North Pacific is known to have the most highly undersaturated intermediate

\footnotetext{
${ }^{1}$ Pacific Marine Environmental Laboratory, NOAA, Seattle, Washington.

${ }^{2}$ Department of Marine Science, University of South Florida, St. Petersburg.

This paper is not subject to U.S. copyright. Published in 1984 by the American Geophysical Union.

Paper number 4C0894.
}

waters of all the oceans [Takahashi et al., 1981]. On this account, it might be one of the first regions where the surface waters become undersaturated as fossil fuel $\mathrm{CO}_{2}$ is progressively elevated over the next several decades.

\section{BACKGROUND}

The degree of saturation of aragonite in seawater is defined as the ratio of the ion product of the concentrations of calcium and carbonate, at the in situ temperature, salinity, and pressure, divided by the stoichiometric solubility product for these conditions

$$
\Omega a=\left[\mathrm{Ca}^{2+}\right] \cdot\left[\mathrm{CO}_{3}{ }^{2-}\right] / K_{\text {spa }}^{\prime}
$$

When $\Omega a>1$, seawater is supersaturated with respect to aragonite, and conversely, when $\Omega a<1$, seawater is undersaturated with respect to aragonite. Since the calcium to salinity ratio in seawater does not vary by more than $1.5 \%$ [Culkin and Cox, 1966], variations in the degree of saturation of aragonite in seawater are primarily governed by variations in the ratio of the ion concentration of carbonate to the stoichiometric solubility product. These variables are independent under natural conditions, and consequently, a study of the factors influencing the degree of saturation of aragonite in seawater must necessarily consider simultaneous variations in both. Since the concentration of carbonate ions in seawater cannot be directly determined, it is calculated from measurable variables such as total carbon dioxide $\mathrm{TCO}_{2}$, total alkalinity $A_{T}$, and $p \mathrm{H}$, assuming the dissociation constants for carbonic acid in seawater are well defined. Takahashi et al. [1976] reviewed the internal consistency of five sets of apparent dissociation constants of carbonic acid and boric acid in seawater using the GEOSECS Atlantic $\mathrm{TCO}_{2}, A_{T}$, and partial pressure of carbon dioxide, $p \mathrm{CO}_{2}$, data. By comparing the measured values of $p \mathrm{CO}_{2}$ with those calculated from $A_{T}$ and $\mathrm{TCO}_{2}$, they found that the apparent dissociation constants determined by Mehrbach et al. [1973] and by Lyman [1956] provided the most consistent data. These conclusions were verified by the comprehensive study by Millero [1979], wherein the effects of temperature pressure and salinity on dissociation constants are described. We have used the equations of Millero [1979] in the present work 


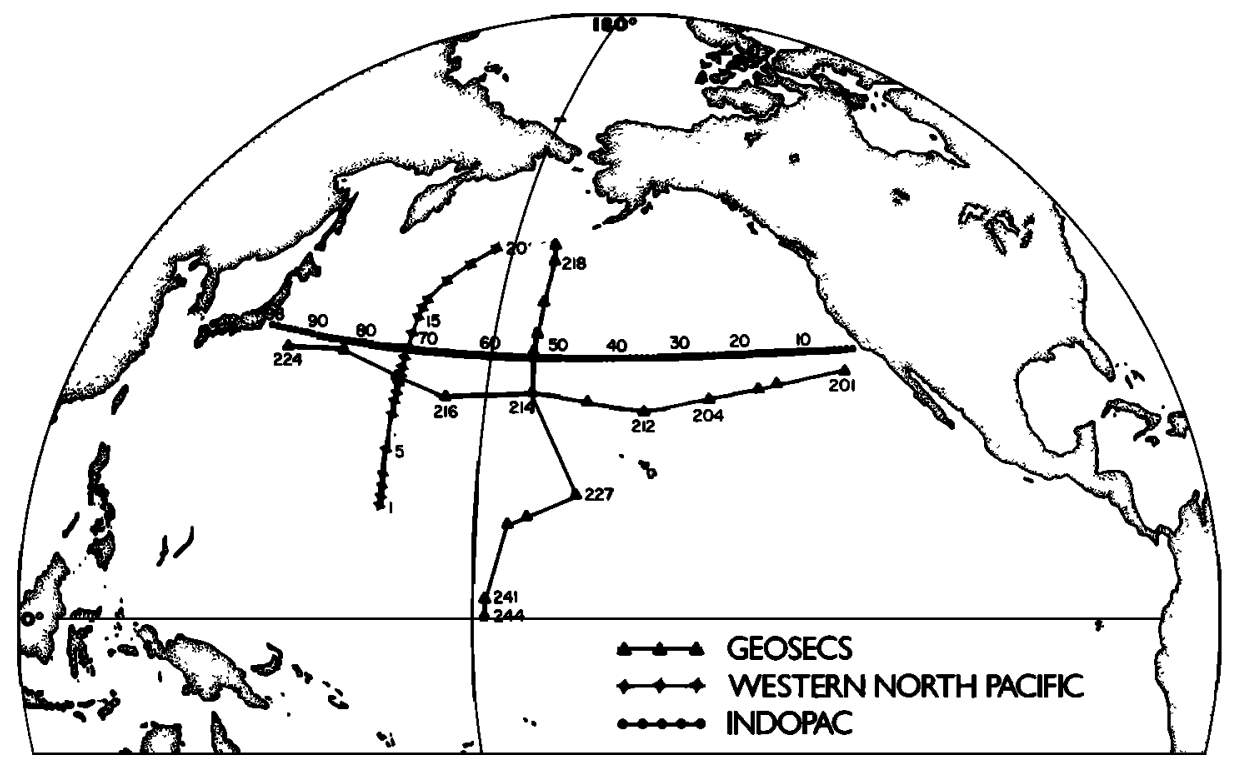

Fig. 1. Locations of stations used for this study. The GEOSECS stations were occupied in 1973, the INDOPAC stations in 1976, and the NOAA western North Pacific stations in 1982.

The stoichiometric solubility product of aragonite in seawater under various conditions has been studied by a number of investigators, and the subject has been extensively reviewed by Morse et al. [1980]. As has been pointed out by these authurs, some of the earlier estimates by MacIntyre [1965], Berner [1976], and Plath and Pytkowicz [1980] were high because the investigators did not take into account the long times required for equilibration. Using equilibration times in excess of 60 days, Morse et al. [1980] found the stoichiometric solubility product for aragonite to be $6.65 \times 10^{-7} \mathrm{~mol}^{2} \mathrm{~kg}^{-2}$ at $25^{\circ} \mathrm{C}$, $35 \%$ salinity, and 1 atmosphere total pressure. This value ranges from as little as $7 \%$ to as much as $42 \%$ lower than previous values for similar conditions. The long-duration solubility studies for aragonite and calcite were recently expanded by $\mathrm{Mucci}$ [1983] to include a temperature range between $5^{\circ} \mathrm{C}$ and $40^{\circ} \mathrm{C}$ and a salinity range between $5 \%$ and $44 \%$.

On the basis of free energy differences between the two polymorphs (i.e., $-230 \mathrm{cal} / \mathrm{mol}$ at $25^{\circ} \mathrm{C}$ and 1 atmosphere pressure), Berner [1976] showed that the theoretical ratio of the solubility products for aragonite and calcite is 1.48 . The ratio of $K_{s p a}^{\prime} / K_{s p c}^{\prime}$ should therefore be close to this value. Since the calcite solubility measurements of Ingle et al. [1973] have been verified by a number of field studies [Broecker and Takahashi, 1978; Sayles, 1980], a comparison of the ratio of the aragonite solubility data at $25^{\circ} \mathrm{C}, 35 \%$ salinity, and 1 atmosphere total pressure with the $25^{\circ} \mathrm{C}, 35 \%$ salinity calcite solubility data of Ingle et al. [1973] should provide further confirmation of the importance of equilibration time for accu- rate aragonite solubility data. Table 1 gives the ratio of $K_{s p a}^{\prime} / K_{s p c}^{\prime}$ versus equilibration time using the calcite solubility data of Ingle et al. [1973] and the aragonite solubility data obtained by various investigators in seawater at $25^{\circ} \mathrm{C}, 1$ atmosphere pressure, and $35 \%$ salinity. The data show that as the equilibration time increases, the ratio of $K_{s p a}^{\prime} / K_{s p c}^{\prime}$ approaches the theoretical value, indicating that the stoichiometric solubility products for aragonite, based on the longer equilibration times [Mucci, 1983], are probably more correct.

\section{SAMPling aNd ANAlytical Methods}

The analytical methods and complete data for the GEOSECS and INDOPAC $\mathrm{TCO}_{2}$ and $A_{T}$ sections are given by Takahashi et al. [1980a] and Scripps Institution of Oceanography [1978], respectively. The details of the potentiometric titrations used in these studies are described by Bos and Williams [1982]. The method is based upon techniques developed by Gran [1952] and later modified by Dyrssen and Sillen [1967] and Edmond [1970]. The titrations were performed with $0.25 \mathrm{~N}$ Baker analytical grade $\mathrm{HCl}$ standardized against gravimetrically prepared sodium borate decahydrate solutions adjusted to an ionic strength of 0.7 using $\mathrm{NaCl}$. The GEOSECS titration data were processed using a Gran plot computer program. As was pointed out by Takahashi et al. [1980a], the program contained a systematic error in the $\mathrm{TCO}_{2}$ calculation. On the basis of independent measurements of $\mathrm{pCO}_{2}$ and $\mathrm{TCO}_{2}$, they applied a correction of $-15 \mu \mathrm{M} / \mathrm{kg}$ to the calculated $\mathrm{TCO}_{2}$ data.

TABLE 1. Aragonite Solubility, Equilibration Times, and Ratio of $K_{s p a}^{\prime} / K_{s p c}^{\prime}$ for $25^{\circ} \mathrm{C}, 35 \%$ Salinity, and 1 Atmosphere Total Pressure

\begin{tabular}{cccl}
\hline $\begin{array}{c}K_{\text {spa }}^{\prime} \\
\mathrm{mol}^{2} \mathrm{~kg}^{-2} \times 10^{-7}\end{array}$ & $\begin{array}{c}\text { Equilibration Time, } \\
\text { days }\end{array}$ & $\frac{K_{\text {spa }}^{\prime}}{K_{\text {spc }}^{\prime}}$ & \multicolumn{1}{c}{ Reference } \\
\hline $8.69( \pm 0.49)$ & 2 & 1.89 & Plath and Pytkowicz [1980] \\
$8.11( \pm 0.25)$ & 4 & 1.76 & Berner [1976] \\
$7.33( \pm 0.31)$ & 10 & 1.59 & MacIntyre [1965] \\
$6.65( \pm 0.12)$ & $7-102$ & 1.54 & Morse et al. $[1980]$ \\
$6.65( \pm 0.12)$ & $7-102$ & 1.54 & Mucci [1983] \\
\hline
\end{tabular}

Ratio of $K_{s p a}^{\prime} / K_{s p c}^{\prime}$ after the data by Ingle et al. [1973]. 
TABLE 2. Station Data for the NOAA Western North Pacific Cruise

\begin{tabular}{|c|c|c|c|c|c|c|c|}
\hline $\begin{array}{l}\text { Depth } \\
\text { m }\end{array}$ & ${ }^{\circ} \mathrm{C}$ & $\underset{\% 0}{a l i n i t y}$ & Sigm & $\begin{array}{c}\mathrm{DO}, \\
\mu M / \mathrm{kg}\end{array}$ & $\begin{array}{c}A_{\mathrm{T}}, \\
\mathrm{meq} / \mathrm{kg}\end{array}$ & $\begin{array}{l}\mathrm{TCO}_{2} \\
\mathrm{~m} M / \mathrm{kg}\end{array}$ & $\frac{T \mathrm{CO}_{2}}{A_{\mathrm{T}}}$ \\
\hline \multicolumn{8}{|c|}{ WNP 3: $16^{\circ} 00.1^{\prime} N, 165^{\circ} 03.4^{\prime} E$, May 29,1982} \\
\hline 1 & 27.270 & 34.854 & 22.527 & 204.4 & 2.296 & 1.965 & 0.856 \\
\hline 26 & & & 22.550 & 204.4 & 2.299 & 1.958 & 0.852 \\
\hline 96 & 26.030 & 35.026 & 23.049 & 209.5 & 2.311 & 1.961 & 0.849 \\
\hline 196 & 21.050 & 35.093 & 24.554 & 184.4 & 2.309 & 2.030 & 0.879 \\
\hline 305 & 15.590 & 34.548 & 25.495 & 178.1 & 2.318 & 2.116 & 0.913 \\
\hline 396 & 9.800 & 34.231 & 26.378 & 161.4 & 2.277 & 2.144 & 0.942 \\
\hline 495 & 7.610 & 34.240 & 26.7 & 80.9 & 2.299 & 2.245 & 0.977 \\
\hline 595 & 6.38 & & 27. & .7 & 2.324 & & 0.987 \\
\hline 792 & 5.340 & 34.488 & 27.2 & 59.6 & 2.352 & 2.311 & 0.983 \\
\hline 994 & 4.420 & 34.516 & 27.359 & 60.9 & 2.371 & 2.332 & 0.984 \\
\hline 1244 & $3.5 t$ & & 27.4 & 72.1 & 2.384 & & 0.992 \\
\hline 1471 & 3.0 & & 27.5 & 84.3 & 2.400 & 2.3 & 0.980 \\
\hline 1957 & 2.15 & 34.622 & 27.6 & 101.2 & 2.422 & 2.361 & 0.975 \\
\hline 2437 & 1.83 & 34.647 & 27.704 & 119.9 & 2.429 & 2.361 & 0.972 \\
\hline 2934 & 1.590 & 34.664 & 27.735 & 134.3 & 2.436 & 2.355 & 0.967 \\
\hline
\end{tabular}

WNP 5: $21^{\circ} 05.5^{\prime} \mathrm{N}, 165^{\circ} 08.7^{\prime} \mathrm{E}$, June I, 1982

$\begin{array}{rrrrrrrc}1 & 26.490 & 35.149 & 22.997 & 220.9 & \ldots & 2.006 & \ldots \\ 30 & 25.666 & 35.223 & 22.311 & 220.8 & 2.310 & 1.949 & 0.844 \\ 100 & 21.866 & 35.186 & 24.400 & 209.2 & 2.314 & 1.991 & 0.860 \\ 200 & 16.896 & 34.804 & 25.390 & 210.4 & 2.285 & 2.019 & 0.884 \\ 300 & 15.006 & 34.643 & 25.697 & 217.3 & 2.285 & 2.043 & 0.894 \\ 400 & 12.896 & 34.347 & 25.910 & 195.4 & 2.272 & 2.091 & 0.920 \\ 500 & 9.256 & 34.182 & 26.439 & 157.5 & 2.278 & 2.157 & 0.947 \\ 600 & 6.616 & 34.119 & 26.779 & 101.8 & 2.303 & 2.238 & 0.972 \\ 800 & 5.156 & 34.321 & 27.121 & 70.4 & 2.344 & 2.316 & 0.988 \\ 1000 & 4.316 & 34.471 & 27.334 & 34.3 & 2.377 & 2.333 & 0.981 \\ 1250 & 3.286 & 34.536 & 27.490 & 84.8 & 2.389 & 2.342 & 0.980 \\ 1500 & 2.796 & 34.559 & 27.553 & 86.5 & 2.402 & 2.347 & 0.977 \\ 2000 & 2.087 & 34.609 & 27.653 & 102.6 & 2.418 & 2.351 & 0.972\end{array}$

$\begin{array}{llllllll}25.120 & 35.247 & 23.496 & 236.9 & 2.324 & 1.981 & 0.852\end{array}$

$\begin{array}{llllllll}43 & 19.980 & 35.119 & 24.861 & 236.6 & 2.309 & 1.977 & 0.856\end{array}$

$\begin{array}{lllllllll}112 & 17.480 & 34.837 & 25.276 & 224.7 & 2.293 & 2.005 & 0.874\end{array}$

$\begin{array}{llllllll}211 & 15.980 & 34.735 & 25.550 & 215.1 & 2.289 & 2.032 & 0.888\end{array}$

$\begin{array}{llllllll}310 & 15.670 & 34.615 & 25.528 & 215.5 & 2.288 & 2.050 & 0.896\end{array}$

$\begin{array}{llllllll}407 & 12.340 & 34.429 & 26.082 & 207.6 & 2.280 & 2.077 & 0.911\end{array}$

$\begin{array}{lllllllll}508 & 9.790 & 34.214 & 26.376 & 174.0 & 2.280 & 2.121 & 0.930\end{array}$

$\begin{array}{llllllll}609 & 6.710 & 34.025 & 26.693 & 200.5 & 2.287 & 2.182 & 0.954\end{array}$

$\begin{array}{llllllll}805 & 4.300 & 34.145 & 27.077 & 70.4 & 2.334 & 2.303 & 0.987\end{array}$

$\begin{array}{llllllll}1006 & 3.550 & 34.326 & 27.297 & 34.3 & 2.367 & 2.357 & 0.996\end{array}$

$\begin{array}{llllllll}1251 & 2.890 & 34.474 & 27.477 & 48.2 & 2.390 & 2371 & 0.992\end{array}$

$\begin{array}{llllllll}1497 & 2.480 & 34.545 & 27.570 & 68.7 & 2.394 & 2.358 & 0.985\end{array}$

$\begin{array}{lllllllll}1977 & 1.910 & 34.616 & 27.673 & 102.6 & 2.410 & 2.350 & 0.975\end{array}$

$\begin{array}{llllllll}2469 & 1.700 & 34.644 & 27.711 & 206.8 & 2.420 & 2.344 & 0.969\end{array}$

$\begin{array}{llllllll}2962 & 1.580 & 34.664 & 27.736 & 234.2 & 2.422 & 2.337 & 0.965\end{array}$

(WNP 8: $30^{\circ} 02.5^{\prime} \mathrm{N}, 165^{\circ} 07.0^{\prime} E$, June 7, 1982

$\begin{array}{rrrrrrrr}1 & 24.200 & 35.053 & 23.626 & 247.4 & 2.305 & 1.983 & 0.860 \\ 40 & 18.190 & 34.893 & 25.145 & 247.0 & 2.293 & 1.981 & 0.864 \\ 109 & 16.420 & 34.761 & 25.469 & 223.4 & 2.287 & 2.002 & 0.875 \\ 208 & 15.550 & 34.723 & 25.638 & 218.1 & 2.293 & 2.032 & 0.886 \\ 307 & 14.070 & 34.591 & 15.858 & 212.4 & 2.281 & 2.046 & 0.897 \\ 406 & 12.300 & 34.395 & 26.064 & 209.3 & 2.280 & 2.082 & 0.913 \\ 505 & 10.040 & 34.265 & 26.373 & 204.9 & 2.282 & 2.113 & 0.926 \\ 604 & 8.060 & 34.104 & 26.564 & 186.2 & 2.284 & 2.153 & 0.943 \\ 704 & 6.120 & 33.996 & 26.747 & 159.6 & 2.299 & 2.210 & 0.961 \\ 802 & 4.880 & 34.053 & 26.941 & 102.2 & 2.320 & 2.272 & 0.979 \\ 1000 & 3.800 & 34.238 & 27.203 & 51.3 & 2.358 & 2.343 & 0.994 \\ 1248 & 3.030 & 34.400 & 27.405 & 32.2 & 2.387 & 2.377 & 0.996 \\ 1496 & 2.560 & 34.494 & 27.522 & 41.3 & 2.409 & 2.389 & 0.992 \\ 1997 & 1.950 & 34.586 & 27.645 & 73.4 & 2.421 & 2.380 & 0.983 \\ 2480 & 1.680 & 34.636 & 27.706 & 108.6 & 2.420 & 2.358 & 0.974 \\ 2964 & 1.540 & 34.660 & 27.736 & 132.1 & 2.424 & 2.346 & 0.968\end{array}$

WNP 9: $32^{\circ} 02.6^{\prime} \mathrm{N}, 165^{\circ} 02.7^{\prime} \mathrm{E}$, June 8,1982

$\begin{array}{rrrrrrrr}1 & 23.990 & 34.860 & 23.542 & 244.3 & 2.286 & 1.973 & 0.863 \\ 38 & 19.663 & 34.875 & 24.757 & 249.3 & 2.294 & 1.976 & 0.861 \\ 107 & 17.043 & 34.796 & 25.349 & 234.3 & 2.291 & 2.004 & 0.875 \\ 207 & 16.430 & 34.778 & 25.480 & 234.3 & 2.288 & 2.010 & 0.878\end{array}$
TABLE 2. (continued)

Depth, Temperature, Salinity, $\quad \mathrm{DO}, \quad \mathrm{A}_{\mathrm{T}}, \quad \mathrm{TCO}_{2}, \frac{T \mathrm{CO}_{2}}{A_{\mathrm{T}}}$ $\mathrm{m} \quad{ }^{\circ} \mathrm{C} \quad \% \quad$ Sigma $t \mu M / \mathrm{kg} \mathrm{meq} / \mathrm{kg} \mathrm{mM} / \mathrm{kg} \quad A_{\mathrm{T}}$

\begin{tabular}{rrrrrrrr}
\hline $\mathbf{4 0 7}$ & 14.334 & 34.556 & 25.775 & 209.4 & 2.283 & 2.053 & 0.899 \\
605 & $\mathbf{9 . 3 1 4}$ & 34.205 & 26.447 & 189.3 & 2.286 & 2.134 & 0.934 \\
804 & $\mathbf{5 . 0 1 8}$ & 34.233 & 27.068 & 119.6 & 2.299 & 2.240 & 0.974 \\
1004 & 4.017 & 34.375 & 27.289 & 57.4 & 2.346 & 2.322 & 0.990 \\
1252 & 3.085 & 34.376 & 27.381 & 42.2 & 2.378 & 2.362 & 0.993 \\
1501 & 2.614 & 34.468 & 27.497 & 42.6 & 2.397 & 2.377 & 0.992 \\
2000 & 2.015 & 34.579 & 27.635 & 68.2 & 2.412 & 2.372 & 0.983 \\
2497 & 1.694 & 34.634 & 27.703 & 104.3 & 2.427 & 2.365 & 0.974 \\
2995 & 1.564 & 34.653 & 27.728 & 130.8 & 2.422 & 2.345 & 0.968
\end{tabular}

WNP 12: $34^{\circ} 57.3^{\prime} \mathrm{N}, 164^{\circ} 58.7^{\prime} E$, June 10,1982

$\begin{array}{lllllll}20.140 & 34.648 & 24.459 & 244.1 & 2.277 & 1.970 & 0.865\end{array}$

$\begin{array}{lllllllll}1 & 20.010 & 34.722 & 25.533 & 249.1 & 2.285 & 1.999 & 0.875\end{array}$

$\begin{array}{llllllll}118 & 13.090 & 34.545 & 26.024 & 223.3 & 2.282 & 2.049 & 0.898\end{array}$

$\begin{array}{lllllllll}218 & 12.470 & 34.450 & 26.073 & 248.5 & 2.272 & 2.040 & 0.898\end{array}$

$\begin{array}{llllllll}318 & 10.820 & 34.287 & 26.225 & 235.8 & 2.270 & 2.063 & 0.909\end{array}$

$\begin{array}{lllllllll}416 & 8.860 & 34.140 & 26.469 & 224.5 & 2.269 & 2.101 & 0.926\end{array}$

$\begin{array}{llllllll}518 & 6.650 & 33.993 & 26.675 & 200.5 & 2.275 & 2.155 & 0.947\end{array}$

$\begin{array}{lllllllll}619 & 5.330 & 33.987 & 26.836 & 137.9 & 2.292 & 2.219 & 0.968\end{array}$

$\begin{array}{llllllll}717 & 4.710 & 34.090 & 26.989 & 92.6 & 2.310 & 2.266 & 0.981\end{array}$

$\begin{array}{llllllll}818 & 4.320 & 34.177 & 27.100 & 72.6 & 2.331 & 2.301 & 0.987\end{array}$

$\begin{array}{llllllll}1017 & 3.480 & 34.295 & 27.279 & 46.9 & 2.363 & 2.346 & 0.993\end{array}$

$\begin{array}{llllllll}1266 & 2.920 & 34.408 & 27.422 & 35.2 & 2.391 & 2.379 & 0.995\end{array}$

$\begin{array}{llllllll}1548 & 2.420 & 34.493 & 27.533 & 43.5 & 2.396 & 2.377 & 0.992\end{array}$

$\begin{array}{llllllll}2040 & 1.930 & 34.584 & 27.645 & 68.7 & 2.409 & 2.372 & 0.985\end{array}$

$\begin{array}{llllllll}2538 & 1.670 & 34.635 & 27.706 & 103.9 & 2.412 & 2.352 & 0.975\end{array}$

$\begin{array}{llllllll}3032 & 1.540 & 34.657 & 27.733 & 127.3 & 2.420 & 2.345 & 0.969\end{array}$

$\begin{array}{llllllll}3526 & 1.480 & 34.672 & 27.750 & 142.5 & 2.419 & 2.334 & 0.965\end{array}$

$\begin{array}{llllllll}4012 & 1.450 & 34.679 & 27.757 & 152.1 & 2.418 & 2.327 & 0.962\end{array}$

$\begin{array}{lllllllll}4515 & 1.470 & 34.684 & 27.760 & 159.0 & 2.417 & 2.323 & 0.961\end{array}$

$\begin{array}{llllllll}5000 & 1.500 & 34.683 & 27.757 & 165.5 & 2.412 & 2.315 & 0.960\end{array}$

WNP $14: 37^{\circ} 58.4^{\prime} \mathrm{N}, 164^{\circ} 59.8^{\prime}$ E, June 12,1982

$\begin{array}{llllllll}1 & 16.480 & 34.012 & 24.879 & 252.7 & 2.265 & 1.976 & 0.872\end{array}$

$\begin{array}{rrrrrrrr}67 & 10.650 & 34.257 & 26.261 & 253.3 & 2.273 & 2.063 & 0.908 \\ 136 & 7.890 & 33.900 & 26.429 & 272.4 & 2.258 & 2.086 & 0.924\end{array}$

$\begin{array}{llllllll}234 & 7.220 & 33.968 & 26.578 & 223.6 & 2.270 & 2.133 & 0.940\end{array}$

$\begin{array}{lllllllll}333 & 5.770 & 33.969 & 26.769 & 163.5 & 2.289 & 2.197 & 0.960\end{array}$

$\begin{array}{llllllll}432 & 4.890 & 34.008 & 26.904 & 118.3 & 2.302 & 2.244 & 0.975\end{array}$

$\begin{array}{llllllll}530 & 4.480 & 34.089 & 27.013 & 87.0 & 2.312 & 2.275 & 0.984\end{array}$

$\begin{array}{llllllll}628 & 4.150 & 34.176 & 27.117 & 65.2 & 2.335 & 2.308 & 0.988\end{array}$

$\begin{array}{llllllll}727 & 3.710 & 34.244 & 27.216 & 50.9 & 2.350 & 2.329 & 0.991\end{array}$

$\begin{array}{lllllllll}825 & 3.420 & 34.298 & 27.288 & 44.3 & 2.362 & 2.347 & 0.994\end{array}$

$\begin{array}{llllllll}1021 & 2.940 & 34.386 & 27.402 & 40.9 & 2.381 & 2.364 & 0.993\end{array}$

$\begin{array}{llllllll}1268 & 2.500 & 34.459 & 27.499 & 40.9 & 2.396 & 2.379 & 0.993\end{array}$

$\begin{array}{lllllllll}1514 & 2.220 & 34.518 & 27.569 & 49.5 & 2.405 & 2.380 & 0.990\end{array}$

$\begin{array}{llllllll}2007 & 1.870 & 34.590 & 27.655 & 78.7 & 2.414 & 2.373 & 0.983\end{array}$

WNP 16: $41^{\circ} 58 . I^{\prime} N, 165^{\circ} 02.6^{\prime} E$, June 15,1982

$\begin{array}{lllllllll}1 & 9.920 & 33.415 & 25.730 & 296.0 & 2.242 & 2.033 & 0.907\end{array}$

$\begin{array}{lllllllll}1 & 45 & 7.290 & 33.647 & 26.316 & 296.8 & 2.243 & 2.058 & 0.918\end{array}$

$\begin{array}{lllllllll}114 & 5.610 & 33.824 & 26.674 & 284.5 & 2.258 & 2.094 & 0.927\end{array}$

$\begin{array}{llllllll}214 & 6.100 & 33.904 & 26.677 & 211.8 & 2.283 & 2.169 & 0.950\end{array}$

$\begin{array}{lllllllll}316 & 4.340 & 33.897 & 26.876 & 160.5 & 2.292 & 2.232 & 0.974\end{array}$

$\begin{array}{llllllll}412 & 4.320 & 34.040 & 26.991 & 94.4 & 2.305 & 2.272 & 0.986\end{array}$

$\begin{array}{llllllll}512 & 3.740 & 34.138 & 27.129 & 57.0 & 2.329 & 2.316 & 0.994\end{array}$

$\begin{array}{lllllllll}612 & 3.810 & 34.249 & 27.210 & 50.4 & 2.336 & 2.320 & 0.993\end{array}$

$\begin{array}{llllllll}710 & 3.450 & 34.303 & 27.289 & 46.1 & 2.354 & 2.339 & 0.994\end{array}$

$\begin{array}{llllllll}810 & 3.250 & 34.376 & 27.366 & 40.4 & 2.360 & 2.345 & 0.994\end{array}$

$\begin{array}{llllllll}1005 & 2.820 & 34.419 & 27.439 & 36.1 & 2.384 & 2.374 & 0.996\end{array}$

$\begin{array}{llllllll}1256 & 2.460 & 34.492 & 27.529 & 39.1 & 2.396 & 2.381 & 0.994\end{array}$

$\begin{array}{llllllll}1505 & 2.190 & 34.545 & 27.594 & 49.5 & 2.405 & 2.379 & 0.989\end{array}$

$\begin{array}{llllllll}1997 & 1.870 & 34.623 & 27.681 & 78.7 & 2.416 & 2.376 & 0.983\end{array}$

$\begin{array}{llllllll}2498 & 1.620 & 34.664 & 27.733 & 110.8 & 2.423 & 2.359 & 0.974\end{array}$

$\begin{array}{lllllllll}2998 & 1.530 & 34.687 & 27.758 & 130.4 & 2.419 & 2.341 & 0.968\end{array}$

WNP 18: $45^{\circ} 17.4^{\prime} N, 167^{\circ} 15.9^{\prime} E$, June 17, 1982

$\begin{array}{lllllllll}1 & 5.620 & 32.903 & 25.944 & 335.2 & 2.226 & 2.064 & 0.927\end{array}$

$\begin{array}{lllllllll}73 & 2.130 & 33.108 & 26.447 & 336.7 & 2.243 & 2.118 & 0.944\end{array}$

$\begin{array}{llllllll}143 & 2.580 & 33.403 & 26.648 & 265.3 & 2.258 & 2.151 & 0.943\end{array}$

$\begin{array}{lllllllll}243 & 3.110 & 33.698 & 26.838 & 136.1 & 2.286 & 2.255 & 0.986\end{array}$

$\begin{array}{llllllll}344 & 3.760 & 33.968 & 26.992 & 87.0 & 2.312 & 2.288 & 0.990\end{array}$

$\begin{array}{llllllll}443 & 3.150 & 34.000 & 27.075 & 53.5 & 2.324 & 2.327 & 1.001\end{array}$ 
TABLE 2. (continued)

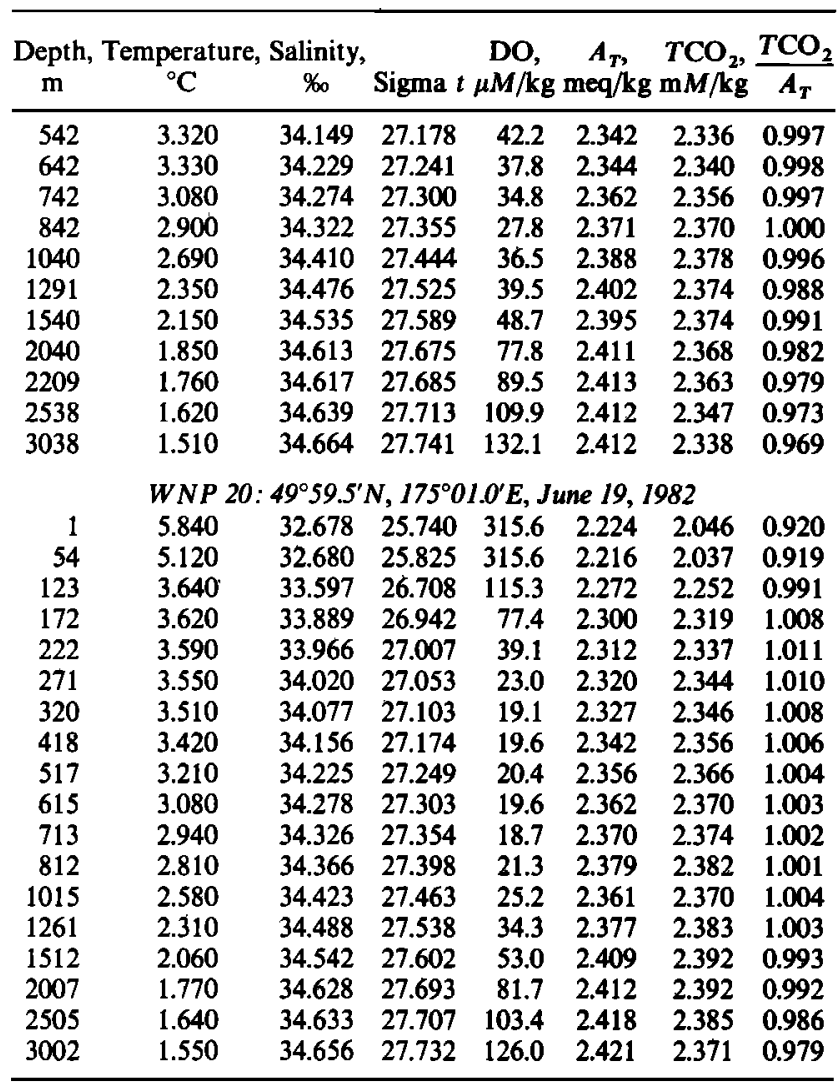

DO, dissolved oxygen.

For the NOAA data, water samples were collected in 30-L Niskin bottles and immediately transferred into 1-L glassstoppered bottles containing $1.0 \mathrm{~mL}$ of a saturated solution of $\mathrm{HgCl}_{2}$ to decrease bacterial oxidation of organic matter prior to analysis. The samples were stored in a dark cold storage room at $4^{\circ} \mathrm{C}$ for as much as 12 hours. The samples were analyzed by the potentiometric method described above using a Brinkman E636 titroprocessor linked to a Hewlett-Packard 85 computer. The data from the titroprocessor were automatically fed into the computer and processed using the modified Gran equations described by Bradshaw et al. [1981]. Alka-

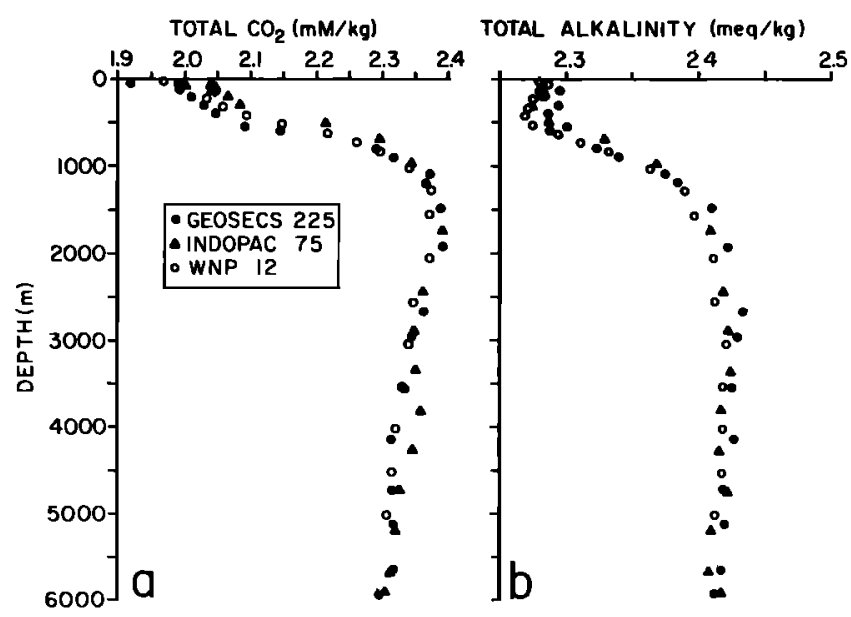

Fig. 2. Vertical profiles of (a) total $\mathrm{CO}_{2}$ and (b) total alkalinity from GEOSECS $225 \quad\left(32^{\circ} 37.0^{\prime} \mathrm{N}, 161^{\circ} 55.0^{\prime} \mathrm{E}\right)$, INDOPAC 75 $\left(35^{\circ} 03.3^{\prime} \mathrm{N}, 164^{\circ} 65.7^{\prime} \mathrm{E}\right)$, and WNP $12\left(34^{\circ} 57.3^{\prime} \mathrm{N}, 164^{\circ} 58.7^{\prime} \mathrm{E}\right)$

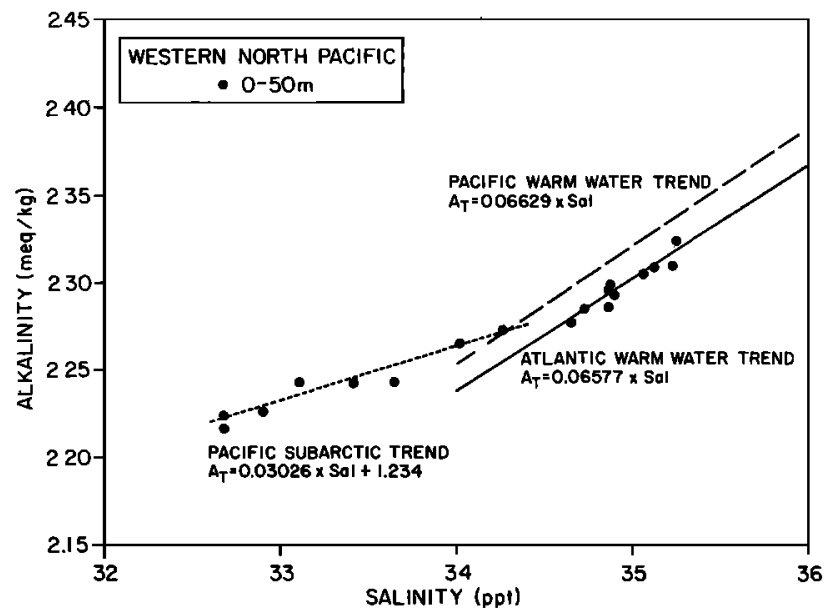

Fig. 3. Plot of $A_{T}$ versus salinity for the NOAA western North Pacific near-surface $(0-50 \mathrm{~m})$ data. The GEOSECS Pacific Subarctic Trend (short-dashed curve), the Pacific Warm Water Trend (longdashed curve), and the Atlantic Warm Water Trend (solid curve) are also given.

linity contributions from boric, silicic, and phosphoric acid were computed from equations similar to those presented by Takahashi et al. [1982] in the GEOSECS Pacific Expedition report. Total borate concentration was computed using the relation given by Culkin [1965]. The dissociation constants of carbonic acid and boric acid are from the work by Almgren et al. [1977]. Potassium chloride was used to adjust the ionic strength of the sodium tetraborate decahydrate standards to 0.7. At each station a blank was determined by titrating aliquots of a $\mathrm{KCl}$ solution containing no borate. The average blank was $4 \mu \mathrm{eq} / \mathrm{L}$. Figure 1 gives the station locations, and Table 2 provides listings of the station number, depth, salinity, temperature, $A_{T}$, and $\mathrm{TCO}_{2}$ for Discoverer cruise RP-14-DI82 in the northwest Pacific.

The equations for aragonite saturation are based on the work by $M$ ucci [1983] in which the degree of in situ saturation is the product of the concentrations of calcium and carbonate ions, at the in situ temperature, salinity, and pressure, divided by the stoichiometric solubility product for those conditions (equation (1)). Calcium concentration is estimated from the salinity [after Takahashi et al., 1980a, b], while the carbonate ion concentration is calculated from the $\mathrm{TCO}_{2}$ and $A_{T}$ data using the dissociation constants of Mehrbach et al. [1973] as revised by Millero [1979]. The stoichiometric solubility product for aragonite is expressed by

$$
\log K_{s p a}^{\prime}-\log K_{s p a}^{\prime}=\left(b_{0}+b_{1} T+b_{2} / T\right) S^{0.5}+C_{0} S+d_{0} S^{1.5}
$$

where $K_{s p a}^{\prime}$ is the stoichiometric solubilty product for ambient conditions; $K^{\prime}{ }_{s p a}^{\circ}$ is the stoichiometric solubility product for $298^{\circ} \mathrm{K}, 35 \%$ salinity, and 1 atmosphere total pressure; $b_{0}=$ $-0.06839, b_{1}=1.728 \times 10^{-3}, b_{2}=88.14, C_{0}=-0.1002$, and $d_{0}=5.942 \times 10^{-3} ; T$ is temperature in degrees Kelvin; and $S$ is salinity in parts per thousand. The pressure effect on solubility is estimated from the equation [Mucci et al., 1982]

$$
\ln \left(K_{s p a}^{\prime} / K_{s p a}^{\prime}\right)=(-\Delta V / R T)(P)
$$

where $P$ is the gauge pressure and the molar volume for aragonite is determined from the data presented by Millero [1979]. A maximum uncertainty of $\pm 12 \mu \mathrm{M} / \mathrm{kg}$ in $\mathrm{TCO}_{2}$ and 


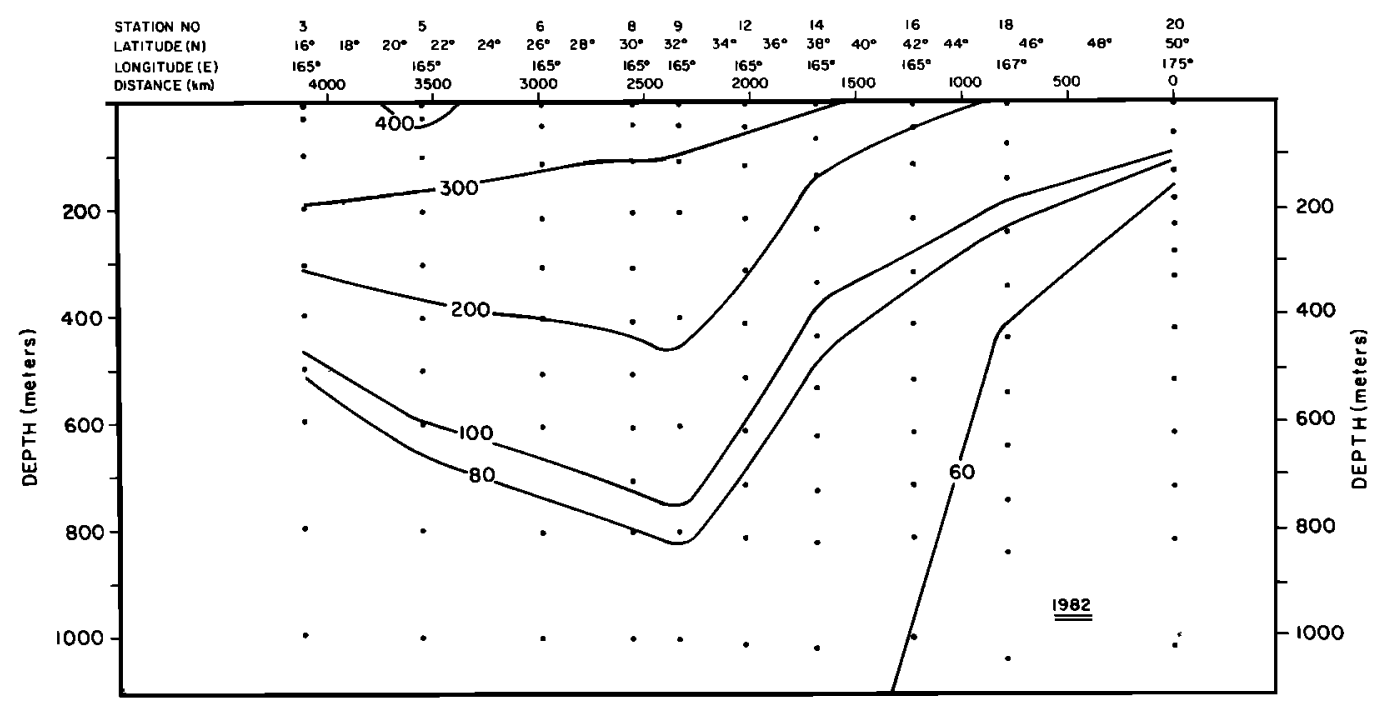

Fig. 4. Percent aragonite saturation in the northwest Pacific roughly along $165^{\circ} \mathrm{E}$ longitude. The data are based upon the NOAA $T \mathrm{TO}_{2}$ and $A_{T}$ data which were collected during May-June 1982.

$\pm 5 \mu \mathrm{eq} / \mathrm{kg}$ in $A_{T}$ leads to an uncertainty of $\pm 5 \%$ in the calculated $\Omega a$.

\section{Results and Discussion}

\section{Relative Consistency of the Data Sets}

Since there are no stations from all three data sets that exactly overlap in location or time of sampling, the relative consistency of the individual data sets is difficult to define. However, three stations, GEOSECS $225\left(32^{\circ} 37.0^{\prime} \mathrm{N}\right.$, $\left.161^{\circ} 55.0^{\prime} \mathrm{E}\right)$, INDOPAC $75\left(35^{\circ} 03.3^{\prime} \mathrm{N}, 164^{\circ} 05.7^{\prime} \mathrm{E}\right)$, and western North Pacific (WNP) $12\left(34^{\circ} 57.3^{\prime} \mathrm{N}, 164^{\circ} 58.7^{\prime} \mathrm{E}\right)$, are within $389 \mathrm{~km}$ of each other and may be used to compare $\mathrm{TCO}_{2}$ and $A_{T}$ data in the deeper portions of the water column where other water mass properties (i.e., temperature and salinity) are virtually the same. Figure 2 shows yertical profiles of $\mathrm{TCO}_{2}$ and $A_{T}$ for the three stations. In the upper $1000 \mathrm{~m}$ of the water column, distinct differences in concentrations of $\mathrm{TCO}_{2}$ and $A_{T}$ exist between the stations. These variations are probably real, because there are distinct variations in temperature and salinity in the upper region of the water column. According to the studies by Shiller and Gieskes [1980] and Kenyon [1983], small-scale variability of water properties in this region of the Pacific is often the result of migrations of the Kuroshio Extension. Below about 3000 the temperature and salinity are virtually the same for the three data sets, and the $\mathrm{TCO}_{2}$ data show reasonably good agreement, with the data from WNP 12 being similar to those from GEOSECS 225 and slightly lower than those from INDOPAC 75. With the possible exception of two INDOPAC 75

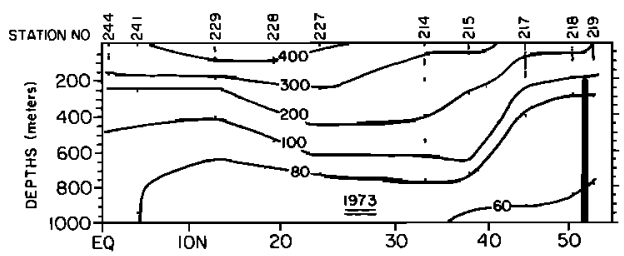

Fig. 5. Percent aragonite saturation in the north central Pacific roughly along $177^{\circ} \mathrm{W}$ longitude. The data are based upon the GEOSECS $\mathrm{TCO}_{2}$ and $A_{T}$ data which were collected during OctoberDecember 1973. samples at 3807 and $4268 \mathrm{~m}$, the deep-water data are all within about $10 \mu \mathrm{M} / \mathrm{kg}$ of each other for any given depth.

Most of the GEOSECS $225 A_{T}$ data appear to be about 2-10 $\mu \mathrm{eq}$ higher for a given depth than either the INDOPAC 75 or the WNP 12 data. These differences are probably primarily a function of the blanks in the different data sets [Takahashi et al., 1980a; Bos and Williams, 1982], which can be illustrated by comparing the $A_{T}$-salinity relationship for nearsurface data (Figure 3 ). The trend lines are reproduced from the GEOSECS data, as discussed by Takahashi et al. [1980a, b]. The GEOSECS Warm Water Trend $\left(>8^{\circ} \mathrm{C}\right)$ indicates a possible systematic difference between the Pacific and Atlantic Warm Water Trends. In contrast, the NOAA data for the northwest Pacific appear more consistent with the Atlantic Warm Water Trend than the Pacific Warm Water Trend, which suggests that the small differences between the NOAA and the GEOSECS data are probably due to calibration errors in the Pacific GEOSECS data. Nevertheless, it should be noted that a systematic difference of $2-10 \mu \mathrm{eg} / \mathrm{kg}$ in $A_{T}$ leads to a difference of about $3 \mu \mathrm{M} / \mathrm{kg}$ in the carbonate ion concentration or about a $4 \%$ difference in the computed value of $\Omega a$. Because these differences are relatively small, we have not made an attempt to correct data sets for these potential errors.

\section{North-South Trends in the Degree of Saturation With Respect to Aragonite}

Figure 4 shows north-south profiles of the degree of aragonite saturation in surface and intermediate waters of the North Pacific along $165^{\circ} \mathrm{E}$ longitude from $16^{\circ} \mathrm{N}$ to $45^{\circ} \mathrm{N}$, and obliquely northeast to $50^{\circ} \mathrm{N}, 175^{\circ} \mathrm{E}$. Figure 5 shows saturation profiles along $177^{\circ} \mathrm{W}$ from the equator to $53^{\circ} \mathrm{N}$. The profiles show that the $100 \%$ saturation horizons are shallowest in the cold-water region north of the Subarctic Front, located near $40^{\circ} \mathrm{N}$. In the northwest Pacific (Figure 4) the $100 \%$ saturation horizon reaches its shallowest depth $(\simeq 100 \mathrm{~m})$ at about $50^{\circ} \mathrm{N}$, whereas in the north central Pacific (Figure 5) the $100 \%$ saturation horizon is slightly deeper $(\simeq 170 \mathrm{~m})$. At both these locations the water is relatively colder $\left(<4^{\circ} \mathrm{C}\right)$ and has a higher $\mathrm{TCO}_{2} / A_{T}$ ratio (see Table 2) than corresponding waters farther to the south. These factors are indicative of a decreasing carbonate ion concentration and an increasing solubility 


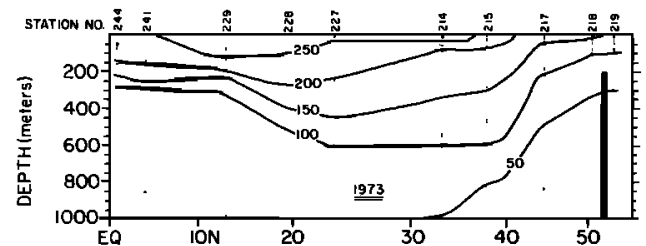

Fig. 6. Carbonate ion concentration in the north central Pacific roughly along $177^{\circ} \mathrm{W}$ longitude.

product such that there is a substantial shoaling of saturation horizons toward the north. These trends are consistent with the aragonite saturation data presented by Feely and Chen [1982] for a similar transect along $150^{\circ} \mathrm{W}$ longitude in the northeast Pacific and also with the calcite saturation data presented by Takahashi [1975] for the GEOSECS northsouth transect.

Between about $45^{\circ} \mathrm{N}$ and $32^{\circ} \mathrm{N}$ in the northwest Pacific and $45^{\circ} \mathrm{N}$ and $25^{\circ} \mathrm{N}$ in the north central Pacific the $100 \%$ saturation horizon increases in depth with decreasing latitude. The maximum depth of the $100 \%$ saturation horizon occurs at about $750 \mathrm{~m}$ at $32^{\circ} \mathrm{N}$ in the northwest Pacific and at about $650 \mathrm{~m}$ in the region between $37^{\circ} \mathrm{N}$ and $25^{\circ} \mathrm{N}$ in the north central Pacific. The downward slopes of these isopleths are greatest near and immediately south of the Subarctic Front. As indicated by the oxygen distributions of Reid [1965] and the ${ }^{14} \mathrm{C}$ and tritium data of Ostlund et al. [1979], mixing and lateral transport of the North Pacific Intermediate Water south of the Subarctic Front induce greater vertical exchange with upper water (probably below the mixed layer) than the subarctic water farther to the north. The shallow level of the horizons north of the Subarctic Front also seems to be a result of the general cyclonic circulation within the Subarctic Gyre where upward vertical mixing produces a doming of property isopleths [Dodimead et al., 1963]. As a result of the increased vertical exchange, the $\mathrm{TCO}_{2} / A_{T}$ ratio decreases rapidly across the front, and the corresponding carbonate ion concentrations increase significantly (Figure 6), producing most of the observed increases in the degree of saturation of these waters with respect to aragonite. For example, the northwest Pacific data (Figure 4) indicate that between $214 \mathrm{~m}$ at station WNP $16\left(41^{\circ} 58.1^{\prime} \mathrm{N}, 165^{\circ} 2.6^{\prime} \mathrm{E}\right)$ and $234 \mathrm{~m}$ at station WNP 14 $\left(37^{\circ} 58.4^{\circ} \mathrm{N}, 164^{\circ} 59.8^{\prime} \mathrm{E}\right)$ the degree of saturation of the water with respect to aragonite increases from about $125 \%$ of saturation to about $142 \%$. Approximately $5 \%$ of this change is due to temperature and salinity effects on the carbonate ion concentration and the stoichiometric solubility product for aragonite. The remaining $95 \%$ of the change is due to the increase in the carbonate ion concentration from 90 to 102

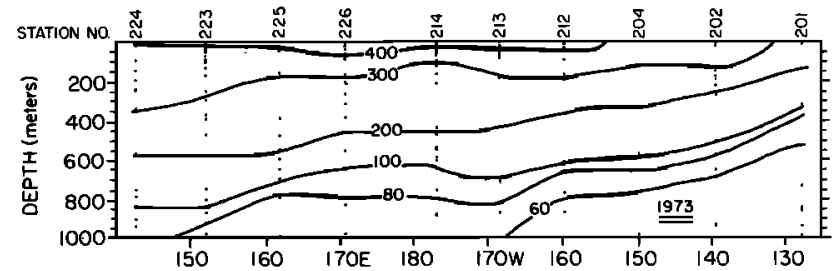

Fig. 7. Percent aragonite saturation roughly along $32^{\circ} \mathrm{N}$ latitude. The data are based upon the GEOSECS $T \mathrm{TO}_{2}$ and $A_{T}$ data which were collected during August-November 1973.

$\mu M / \mathrm{kg}$, resulting from a change in the $T \mathrm{CO}_{2} / A_{T}$ ratio from 0.950 to 0.940 (see Table 2). Thus the increase in carbonate ion concentration due to the decrease in the $\mathrm{TCO}_{2} / A_{T}$ ratio is about 10 times more important to aragonite solubility than changes due to temperature and salinity.

South of $30^{\circ} \mathrm{N}$ in the northwest Pacific and about $24^{\circ} \mathrm{N}$ in the north central Pacific the $100 \%$ saturation horizon for aragonite decreases in depth by about $150-300 \mathrm{~m}$. The slopes of the isopleths follow the general upward sloping trends of the isopycnal surfaces in these regions [J. Cline, unpublished data, 1983; Craig et al., 1981]. This trend in the slope of the $100 \%$ horizon appears to be mainly associated with circulation around the center of the Subtropical Gyre [Reed, 1973]. Furthermore, there is a suggestion in Figures 5 and 6 that the maximum depth of the saturation isopleths tends to shift poleward with increasing depth. This also is in agreement with the distributions of thermohaline properties in the work by Reed [1973] and with the conclusions of Reid and Arthur [1975] that the Subtropical Gyre shifts northward with increasing depth.

\section{Evaluation of the 100\% Saturation}

Horizon at $50^{\circ} \mathrm{N}, 175^{\circ} \mathrm{E}$

Although the degree of aragonitic saturation, $\Omega a$, appears to be reasonably well defined according to our method of calculation, in one instance we felt it worthwhile to compare our results with ancillary measurements. Our calculations at station WNP $20\left(49^{\circ} 59.5^{\prime} \mathrm{N}, 175^{\circ} 01.0^{\prime} \mathrm{W}\right)$ indicate an unusually shallow aragonite saturation depth $(\simeq 100 \mathrm{~m})$ and an intense vertical $\mathbf{\Omega} a$ gradient. The substantial aragonite undersaturation at depths of $123 \mathrm{~m}$ and greater $(\Omega a \leq 0.72)$ indicates that aragonite dissolution will proceed at a substantial rate under in situ conditions. In an attempt to directly verify the existence of undersaturation at shallow depths at this station, the saturation states at 123 and $418 \mathrm{~m}$ were directly $\epsilon_{\text {samined through }}$ aragonite dissolution experiments on freshly collected materials under in situ conditions.

TABLE 3. In Vitro Examination of Aragonite Saturation at $49^{\circ} 59.5^{\prime} \mathrm{N}, 175^{\circ} 01.0^{\prime} \mathrm{E}$

\begin{tabular}{|c|c|c|c|c|c|}
\hline $\begin{array}{c}\text { Seawater } \\
\text { Source } \\
\text { Depth, } \\
\text { m }\end{array}$ & $\begin{array}{c}\text { Aragonitic Materials and } \\
\text { Mass, mg }\end{array}$ & $\begin{array}{c}\text { Temperature, } \\
{ }^{\circ} \mathrm{C}\end{array}$ & $\begin{array}{l}\text { Pressure, } \\
\text { atm }\end{array}$ & $\begin{array}{c}\text { Initial } \\
\text { Percent } \\
\boldsymbol{\Omega a}\end{array}$ & $\Delta p \mathbf{H}^{*}$ \\
\hline 123 & aragonite fragments, 3.96 & 3.6 & $\leq 24$ & 69.7 & $0.06 \pm 0.01$ \\
\hline 123 & Cuvierina columnella (2), 9.42 & 3.6 & $\leq 14$ & 71.1 & $0.09 \pm 0.01$ \\
\hline 418 & Diacria trispinosa, 13.97 & 3.6 & 39 & 55.0 & $0.07 \pm 0.02$ \\
\hline 418 & Limacina helicina (3), 1.24 & 3.6 & 41 & 54.8 & $0.05 \pm 0.02$ \\
\hline
\end{tabular}

*The $\Delta p H$ shows $p H$ increase in 9-mL sample vials relative to controls which contained no solid aragonite. The uncertainties provided with each $\Delta p H$ reflect the $p H$ variability observed in three control vials (containing no solid carbonate) for each seawater source. The duration of each experiment was $27.0 \pm 1.5$ hours. 


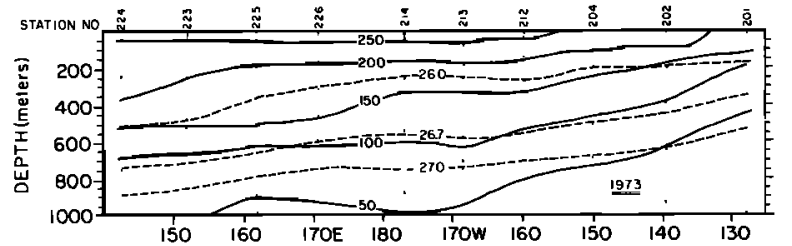

Fig. 8. Carbonate ion concentration roughly along $32^{\circ} \mathrm{N}$ latitude. The 26.0, 26.7, and 27.0 sigma $t$ surfaces are presented as dashed curves.

Our experiments were performed on aragonite fragments and whole pteropod tests collected in the western North Pacific using free-floating sediment traps (P. R. Betzer et al., unpublished manuscript, 1984). Aragonite materials were housed in 9-mL glass vials containing seawater collected at depths of 123 and $418 \mathrm{~m}$. To retard respiration of microorganisms, each seawater sample contained $2 \times 10^{-5} M \mathrm{Hg}^{(\mathrm{II})}$. Each reaction vial, sealed with a plastic cap, was housed in a high-pressure cell thermostated at $3.6^{\circ} \mathrm{C}$. The pressure of each of four sample cells was maintained near the appropriate in situ values $(\sim 12$ and $\sim 40 \mathrm{~atm}$ ). additional reference cells, containing unfiltered seawater from each depth but no added carbonates, were used for comparison with the carbonate-containing sample cells. The $p H$ of the seawater samples were measured before and after a 27-hour period, during which all samples were gently oscillated through a $90^{\circ}$ angle at approximately seven repetitions per minute. Dissolution of calcium carbonate in these experiments is revealed as an increase in $p \mathrm{H}$ :

$$
\mathrm{CaCO}_{3}(\mathrm{~s})+\mathrm{H}^{+} \rightleftarrows \mathrm{Ca}^{2+}+\mathrm{HCO}_{3}^{-}
$$

The results of these experiments on aragonite fragments and three pteropod species are shown in Table 3. The final column provides the $p \mathrm{H}$ increase which occurred in each aragonitecontaining sample cell relative to the reference cells.

The substantial $p \mathrm{H}$ increase in each of our sample vials compared to the reference vials indicates that substantial aragonite dissolution occurred for each of our four samples. These results support our conclusion that the saturation horizon at this station occurs at a depth less than $123 \mathrm{~m}$. Furthermore, we note that the substantial calculated undersaturation at $123 \mathrm{~m}$ and the reasonably direct interpretation of our dissolution experiments make alteration of this conclusion unlikely.

\section{East-West Trends in the Degree of Saturation With Respect to Aragonite}

The east-west profiles of the degree of aragonite saturation in surface and intermediate waters are given in Figures 7 and 10. Figure 7 shows the results based upon the GEOSECS
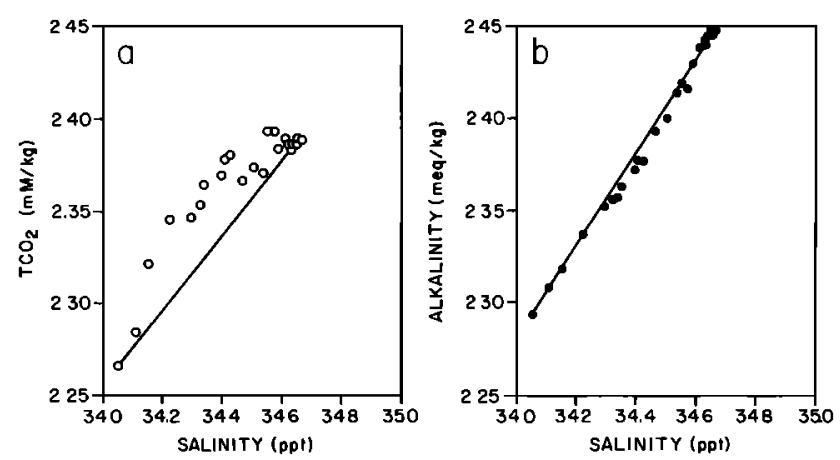

Fig. 9. Plot of (a) total $\mathrm{CO}_{2}$ versus salinity and $(b)$ total alkalinity versus salinity from GEOSECS $201\left(34^{\circ} 11.0^{\prime} \mathrm{N}, 127^{\circ} 54.0^{\prime} \mathrm{W}\right)$ for the intermediate water depths where the temperature-salinity relationship is linear. The positive excess of $\mathrm{TCO}_{2}$ is due to oxidation of organic matter.

$\mathrm{TCO}_{2}$ and $\mathrm{A}_{\mathrm{T}}$ data for measurements made roughly along $32^{\circ} \mathrm{N}$ latitude (range: $30^{\circ} 00.0^{\prime} \mathrm{N}$ to $34^{\circ} 58.0^{\prime} \mathrm{N}$ ), and Figure 10 shows the results based upon the more detailed INDOPAC data from observations taken along $35^{\circ} \mathrm{N}$ latitude (range: $34^{\circ} 56.5^{\prime} \mathrm{N}$ to $35^{\circ} 03.3^{\prime} \mathrm{N}$ ). Both profiles indicate a general trend of increasing depth of the $100 \%$ saturation horizon from about 140 to $280 \mathrm{~m}$ in the northeast Pacific (GEOSECS station 201 and INDOPAC station 01) to a little more than 750 $m$ in the northwest Pacific (GEOSECS station 224 and INDOPAC station 98). This increase in the depth of the $100 \%$ saturation horizon is, in large part, due to a general increase in the carbonate ion concentration along the transect (Figure 8). Only a small part of the shift can be ascribed to the influence of temperature and salinity on carbonate ion equilibria and aragonite solubility. For example, the last three columns in Table 4 show the changes in the degree of saturation that would occur if a parcel of water having the same $\mathrm{TCO}_{2}$ and $A_{T}$ concentrations as that from $444 \mathrm{~m}$ at GEOSECS station 201 were placed at the same temperature, pressure, and salinity conditions as those found at GEOSECS station 224 . The increase in temperature from $6.00^{\circ} \mathrm{C}$ to $15.06^{\circ} \mathrm{C}$ and an increase in the salinity from $34.108 \%$ to $34.635 \%$ (at constant $\mathrm{TCO}_{2} / A_{\mathrm{T}}$ ratio) cause approximately a $10 \%$ increase in the degree of saturation. The actual increase in the degree of saturation between the two stations $(\simeq 300 \%)$ is primarily due to the decrease in the $\mathrm{TCO}_{2} / A_{T}$ ratio from 0.994 to 0.889 and a concomitant increase in the carbonate ion concentration from 51 to $174 \mu M / \mathrm{kg}$. Thus the degree of saturation of these intermediate waters primarily depends upon the extent to which they are enriched in $\mathrm{TCO}_{2}$ in relation to $A_{T}$. The concentration variations of these two parameters are governed by

TABLE 4. Example of the Effects of Changes in Temperature, Salinity, and the Ratio of $\mathrm{TCO}_{2} / A_{T}$ on the Degree of Saturation With Respect to Aragonite for a Parcel of Water at $444 \mathrm{~m}$ From GEOSECS Station 201

\begin{tabular}{lcccc}
\hline & & \multicolumn{2}{c}{$\begin{array}{c}\text { Physical-Chemical Alterations (Final Conditions), } \\
\text { GEOSECS 224 (445 m) }\end{array}$} \\
\cline { 3 - 5 } & $\begin{array}{c}\text { Initial Conditions, } \\
\text { GEOSECS } 201(444 \mathrm{~m})\end{array}$ & Temperature & $\begin{array}{c}\text { Temperature and } \\
\text { Salinity }\end{array}$ & $\begin{array}{c}\text { Ternperature and } \\
\text { Salinity and } T C \mathrm{O}_{2} / A_{T}\end{array}$ \\
\hline Temperature, ${ }^{\circ} \mathrm{C}$ & 6.00 & 15.06 & 15.06 & 15.06 \\
Salinity, \%o & 34.108 & 34.108 & 34.635 & 34.635 \\
$T \mathrm{CO}_{2} / A_{T}$ & 0.994 & 0.994 & 0.994 & 0.889 \\
$\mathrm{CO}_{3}{ }^{2-}, \mu M / \mathrm{kg}$ & 51.1 & 55.1 & 55.1 & 179 \\
$\Omega a, \%$ & 61.5 & 68.4 & 68.1 & 240 \\
\hline
\end{tabular}




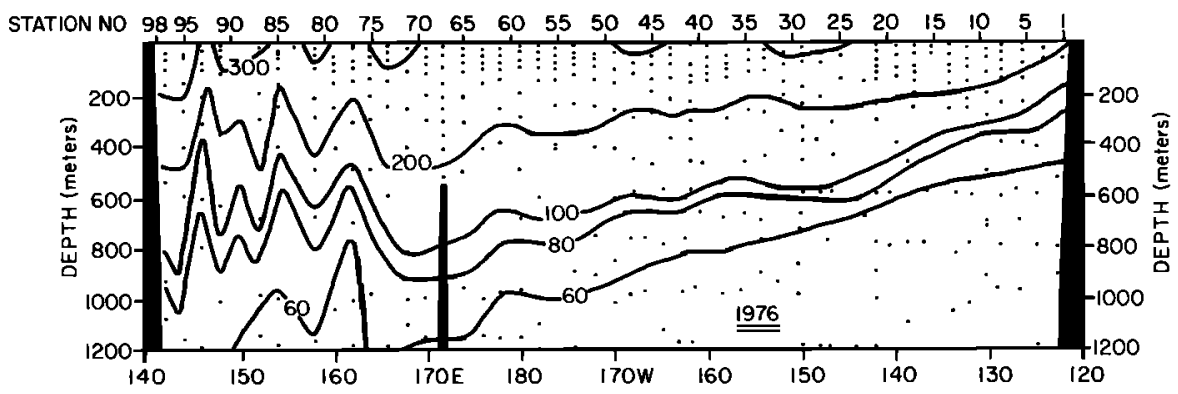

Fig. 10. Percent aragonite saturation along $35^{\circ} \mathrm{N}$ latitude. The data are based upon the INDOPAC TCO ${ }_{2}$ and $A_{T}$ data which were collected during April 1976.

mixing and biogeochemical processes such that in most cases, $\mathrm{TCO}_{2}$ increases more rapidly with depth than does the alkalinity. The reason for this is that whereas the $\mathrm{TCO}_{2}$ is increased in subsurface waters as a result of a relatively rapid process of microbiological oxidation of organic matter falling from the euphotic zone, the increase in alkalinity is due to the dissolution of calcareous tests, a process which proceeds much more slowly. The buildup of $T \mathrm{CO}_{2}$ relative to $A_{T}$ significantly decreases the carbonate ion concentration and the degree of aragonite saturation. Both ${ }^{14} \mathrm{C}$ and tritium data indicate that the intermediate waters of the northeast Pacific are not as well ventilated as those intermediate waters of the northwest Pacific [Ostlund et al., 1979], and consequently, there is a relative enhancement of $\mathrm{CO}_{2}$ from oxidation and respiration processes (Figure 9) and from upwelling near the continental margin [Bryden, 1978]. This effect is evidenced by the upward sloping isopleths of the carbonate ion concentrations which intersect the isopleths of sigma $t$ at about 200-500 m near GEOSECS stations 202 and 201 in Figure 8. The increased acidity resulting from these processes decreases the carbonate ion concentration, with the result that the waters are undersaturated much closer to the surface. This effect is significantly enhanced in productive upwelling areas such as those along the continental margin of North America and those in the subarctic waters north of the Subarctic Front. In the oligotrophic waters of the central and western Pacific the excess of $\mathrm{TCO}_{2}$ over $A_{T}$ is diminished significantly, and mixing processes predominate.

Another interesting feature evident in the east-west saturation profiles from the INDOPAC transect is the high degree of lateral variability in the northwest Pacific. Such variability is much less evident in the data from the northeast Pacific. Zonal variability in the northwest Pacific has also been observed for temperature and salinity data [Kenyon, 1983] and for normalized $\mathrm{TCO}_{2}$ and $A_{T}$ data [Shiller and Gieskes, 1980]. In both cases the authors ascribed this feature to the complexity of the excursions and eddies associated with the Kuroshio Extension. The highly saturated waters are apparently associated with the warm saline waters of Kuroshio Extension origin. However, from the $\mathrm{TCO}_{2}$ and $A_{T}$ observations presented by Shiller and Gieskes [1980], most of the lateral variability appears to be limited to the upper 1500 of the water column. Thus local differences in circulation and water mass characteristics can have a profound effect on the local saturation state with respect to aragonite in this region of the North Pacific.

\section{Possible Effects of Fossil $\mathrm{CO}_{2}$ on the Degree of Saturation in Surface Waters}

As stated in the introduction of this paper, in recent years there has been some concern about the possible effects of fossil fuel-derived $\mathrm{CO}_{2}$ on the saturation state of the surface oceans with respect to calcite and aragonite. The subject was recently reviewed in a general way by Broecker et al. [1979], who stated that in a typical warm tropical ocean the mixed-layer water will not become undersaturated with respect to aragonite until the partial pressure of $\mathrm{CO}_{2}$ in the atmosphere is increased to a level of about $1760 \mu \mathrm{atm}$, a condition the authors stated would not occur during the next several decades. The underlying assumption of their model is that the surface ocean $p \mathrm{CO}_{2}$ would be in equilibrium with $p \mathrm{CO}_{2}$ in the atmosphere. In the North Pacific the recent data of Takahashi et al. [1983] indicate that this assumption is basically true, except for regions near the equator $\left(10^{\circ} \mathrm{N}\right.$ to $\left.10^{\circ} \mathrm{S}\right)$, where the surface waters are supersaturated with respect to $\mathrm{pCO}_{2}$, and in the northwest Pacific along the Subarctic Front, where the surface waters are undersaturated with respect to $p \mathrm{CO}_{2}$. Thus there are large regions of the North Pacific where the model should be generally applicable.

Figure 11 shows a plot of the relationship between carbonate ion concentration and the partial pressure of $\mathrm{CO}_{2}$ for three representative surface water samples from our northwest Pacific data set. The solid line shows the equilibrium carbonate ion concentration for aragonite saturation based upon the equations discussed earlier. The dashed curve, representing warm water conditions, shows that undersaturation will occur at a $\mathrm{pCO}_{2}$ value of approximately $2085 \mu \mathrm{atm}$, which is similar to the value predicted by Broecker et al. [1979] for tropical surface waters. However, the curves representing progressively colder, less saline conditions indicate much lower values of $\mathrm{pCO}_{2}$ are sufficient to initiate undersaturation. In the coldest waters, representative of northern subarctic surface waters, undersaturation will occur at $p \mathrm{CO}_{2}$ values as low as $650 \mu \mathrm{atm}$. Thus for those surface waters that maintain equilibrium with the atmosphere, a consequence of increasing atmospheric $\mathrm{pCO}_{2}$ should be the onset of undersaturation of northern sub-

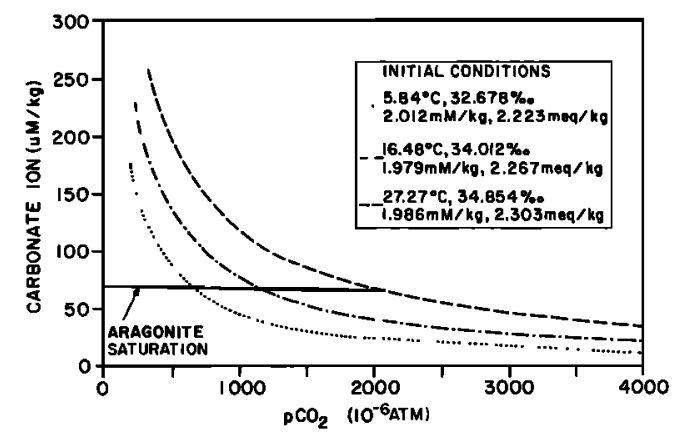

Fig. 11. Plots of the concentration of carbonate ion as a function of $p \mathrm{CO}_{2}$ at constant salinity and alkalinity for three surface water samples from the northwest Pacific spanning the range of conditions usually observed in surface waters of the North Pacific. 
arctic surface waters (at $p \mathrm{CO}_{2}>650 \mu \mathrm{atm}$ ) followed by a steady progression of undersaturation to the south and west. On the basis of recent projections [Keeling, 1980], estimated $\mathrm{pCO}_{2}$ values for the middle of the next century will probably range between 650 and $1240 \mu \mathrm{atm}$. Consequently, undersaturation of some regions of the northern subarctic waters could occur during the second half of the next century.

\section{Conclusions}

The saturation state of the surface and intermediate waters of the North Pacific with respect to aragonite is largely dependent upon the carbonate ion concentration, variations of which are principally due to mixing and biological processes. Large gradients in saturation state occur in the vicinity of the Subarctic Front, particularly in the northwest Pacific. This is because of the extensive mixing which is a result of the formation and lateral transport of the North Pacific Intermediate Water. Our calculations indicate that one possible effect of fossil $\mathrm{CO}_{2}$ on the degree of aragonite saturation in surface waters will be a steady progression of undersaturation starting in the northern North Pacific and moving steadily to the southern and western North Pacific, with the first sign of undersaturation possibly occurring as early as the second half of the next century.

Acknowledgments. The authors express their appreciation to Captain R. Speer and the crew of the NOAA ship Discoverer for their support. Special thanks are due Chief Bosun W. Sherril, who effectively directed the launching and retrieval of the sediment traps, and $\mathbf{R}$. Jolley, who organized much of the collection and processing efforts aboard the Discoverer. We are also indebted to A. Mucci for providing us with a preprint of his manuscript; G. J. Massoth of the Pacific Marine Environmental Laboratory for performing the total carbon dioxide and alkalinity titrations; and D. Bos and A. Bradshaw for providing valuable help with the INDOPAC and GEOSECS data. This work was supported by grants from the Air Resources Laboratory of NOAA to the University of South Florida (grant NA80RAD00020) and the Pacific Marine Environmental Laboratory. We thank L. Machta, director of the Air Resources Laboratory, for his continued interest and support of this component of the NOAA marine $\mathrm{CO}_{2}$ research program in the Pacific Ocean. The authors also thank T. Takahashi, H. C. Curl, Jr., J. Cline, R. Reed, and two reviewers for providing extremely helpful comments on earlier versions of this manuscript. Contribution 642 from the Pacific Marine Environmental Laboratory.

\section{REFERENCES}

Almgren, T., D. Dyrssen, and M. Strandberg, Computerized highprecision titrations of some major constituents of sea water onboard the R. V. Dmitry Mendeleev, Deep Sea Res., 24, 325-364, 1977.

Berner, R. A., The solubility of calcite and aragonite in seawater at atmospheric pressure and 34.5\% salinity, Am. J. Sci., 276, 713-730, 1976.

Bos, D. L., and R. T. Williams, History and development of the GEOSECS alkalinity titration system, Proceedings on Workshop on Oceanic $\mathrm{CO}_{2}$ Standardization, Carbon Dioxide Effects Research and Assessment Program, edited by H. G. Ostlund and D. Dyrssen, Rep. CONF-7911173, pp. 42-59, U.S. Dep. of Energy, Washington, D. C., 1982.

Bradshaw, A. C., P. G. Brewer, D. K. Shafer, and R. T. Williams, Measurements of total carbon dioxide and alkalinity by potentiometric titration in the GEOSECS program, Earth Planet. Sci. Lett., 55, 99-115, 1981.

Broecker, W. S., and T. Takahashi, The relationship between lysocline depth and in situ carbonate ion concentration, Deep Sea Res., 25, 65-95, 1978.

Broecker, W. S., Y. A. Li, and T. H. Peng, Carbon dioxide-Man's unseen artifact, in Impingement of Man on the Oceans, edited by D. W. Hood, pp. 287-324, Wiley-Interscience, New York, 1971.

Broecker, W. S., T. Takahashi, H. J. Simpson, and T. H. Peng, Fate of fossil fuel carbon dioxide and the global carbon budget, Science, 206, 409-418, 1979.
Bryden, H. L., Mean upwelling velocities on the Oregon continental shelf during summer 1973, Estuarine Coastal Mar. Sci., 7, 311-327, 1978.

Craig, H., W. S. Broecker, and D. Spencer, GEOSECS Pacific Expedition, vol. 4, Sections and Profiles, National Science Foundation, Washington, D. C., 1981.

Culkin, F., The major constituents of sea water, in Chemical Oceanography, vol. 1, edited by J. P. Riley and G. Skirrow, pp. 121-158, Academic, New York, 1965.

Culkin, F., and R. A. Cox, Sodium, potassium, magnesium, calcium, and strontium in seawater, Deep Sea Res., 13, 789-804, 1966.

Dodimead, A. J., F. Favorite, and T. Hirano, Salmon of the North Pacific Ocean, 2, Review of oceanography of the subarctic Pacific region, Int. North Pac. Fish. Comm. Bull., 13, 1-195, 1963.

Dyrssen, D., and L. G. Sillen, Alkalinity and total carbonate in seawater; A plea for P-T-independent data, Tellus, 19, 113-121, 1967.

Edmond, J. M., High precision determination of titration alkalinity and total carbon dioxide of seawater by potentiometric titration, Deep Sea Res., 17, 737-750, 1970.

Fairhall, A. W., Accumulation of fossil $\mathrm{CO}_{2}$ in the atmosphere and the sea, Nature London, 245, 20-23, 1973.

Feely, R. A., and C. T. A. Chen, The effect of excess $\mathrm{CO}_{2}$ on the calculated calcite and aragonite saturation horizons in the northeast Pacific, Geophys. Res. Lett., 9, 1294-1297, 1982.

Gran, G., Determination of the equivalence point in potentiometric titrations, 2, Analyst, 77, 661-671, 1952.

Ingle, S. E., C. H. Culberson, J. E. Hawley, and R. M. Pytkowicz, The solubility of calcite in sea water at atmospheric pressure and $35 \%$ salinity, Mar. Chem., J, 295-307, 1973.

Keeling, C. D., The oceans and biosphere as future sinks for fossil fuel carbon dioxide, in Interactions of Energy and Climate, edited by W. Bach, J. Pankrath, and J. Williams, pp. 129-147, D. Reidel, Hingham, Mass., 1980.

Kenyon, K., Sections along $35^{\circ} \mathrm{N}$ in the Pacific, Deep Sea Res., Part $A, 30(4), 349-369,1983$.

Lyman, J., Buffer mechanism of seawater, Ph.D thesis, 196 pp., Univ. of Calif., Los Angeles, 1956.

MacIntyre, W. G. The temperature variation of the solubility product of calcium carbonate in sea water, Rep. 200, Fish. Res. Board of Can., Ottawa, 153 pp., 1965.

Mehrbach, C., C. H. Culberson, J. E. Hawley, and R. M. Pytkowicz, Measurements of the apparent constants of carbonic acid in seawater at atmospheric pressure, Limnol. Oceanogr., 18, 897-907, 1973.

Millero, F. J., The thermodynamics of the carbonate system in seawater, Geochim. Cosmochim. Acta, 43, 1651-1661, 1979.

Morse, J. W., A. Mucci, and F. J. Millero, The solubility of calcite and aragonite in seawater of $35 \%$ salinity at $25^{\circ} \mathrm{C}$ and atmospheric pressure, Geochim. Cosmochim. Acta, 44, 85-94, 1980.

Mucci, A., The solubility of calcite and aragonite in seawater at various salinities, temperatures and 1 atmosphere total pressure, Am. J. Sci., 283, 780-799, 1983.

Mucci, A., F. J. Millero, and J. W. Morse, Comment on "The solubility of aragonite in seawater," Geochim. Cosmochim. Acta, 46, 105-107, 1982.

Ostlund, H. G., R. Berscher, R. Oleson, and M. J. Ferguson, GEOSECS Pacific radio carbon and tritium results, Data Rep. 8, Tritium Lab., Rosenstiel Sch. of Mar. and Atmos. Sci., Miami, Fla., 1979.

Plath, D. C., and R. M. Pytkowicz, The solubility of aragonite in seawater at $25.0^{\circ} \mathrm{C}$ and $32.62 \%$ salinity, Mar. Chem., 10, 3-7, 1980.

Reed, R. K., Distribution and variation of physical properties along the Seamap standard section, Tech. Rep. ERL 292-PMEL-20, pp. 1-16, U.S. Dep. of Commer., Boulder, Colo., 1973.

Reid, J. L., Intermediate Waters of the Pacific Ocean, Johns Hopkins Oceanogr. Stud., vol. 2, pp. 39-79, Johns Hopkins Press, Baltimore, Md., 1965.

Reid, J. L., and R. S. Arthur, Interpretation of maps of geopotential anomaly for the deep Pacific Ocean, J. Mar. Res., 33, 37-52, 1975.

Sayles, F. L., The solubility of $\mathrm{CaCO}_{3}$ in seawater at $2^{\circ} \mathrm{C}$ based upon in situ sampled pore water composition, Mar. Chem., 9, 223-235, 1980.

Scripps Institution of Oceanography, Physical, chemical and biological data, INDOPAC Expedition, legs I, II, III, VII, VIII, XV, XVI, March, 1976-July, 1977, Data Rep. Ref. 78-21, Univ. of Calif. at San Diego, La Jolla, 1978.

Shiller, A. M., and J. M. Gieskes, Processes affecting the oceanic distributions of dissolved calcium and alkalinity, J. Geophys. Res., $85,2719-2727,1980$. 
Skirrow, G., and M. Whitfield, The effect of increases in the atmospheric carbon dioxide content on the carbonate ion concentration of surface ocean water at $25^{\circ} \mathrm{C}$, Limnol. Oceanogr., 20(1), 103-108, 1975.

Takahashi, T., Carbonate chemistry of seawater and the calcite compensation depth in the ocean, Dissolution of Deep-Sea Carbonates, Spec. Publ. Cushman Found. Foraminiferal Res., 13, 11-26, 1975.

Takahashi, T., P. Kaiteris, W. S. Broecker, and A. E. Bainbridge, An evaluation of the apparent dissociation constants of carbonic acid in seawater, Earth Planet. Sci. Lett., 32, 458-467, 1976.

Takahashi, T., W. S. Broecker, A. E. Bainbridge, and R. F. Weiss, Carbonate chemistry of the Atlantic, Pacific and Indian Oceans: Results of the GEOSECS Expedition 1972-1978, Tech. Rep. ICUI-8, Lamont-Doherty Geol. Observ., Palisades, N. Y., 1980a.

Takahashi, T., W. S. Broecker, S. R. Werner, and A. E. Bainbridge, Carbonate chemistry of the surface waters of the world oceans, in Isotope Marine Chemistry, edited by E. Goldberg. Y. Horibe, and K. Saruhushi, pp. 291-326, Udinda-Rokakuko, Tokyo, 1980b.

Takahashi, T., W. S. Broecker, and A. E. Bainbridge, The alkalinity and total carbon dioxide concentration in the world oceans, in Carbon Cycle Modelling, edited by B. Bolin, pp. 271-286, John Wiley, New York, 1981.

Takahashi, T., R. T. Williams, and D. L. Bos, Carbonate chemistry in GEOSECS Pacific Expedition, vol. 3, Hydrographic Data, edited by
W. S. Broecker, D. W. Spencer, and H. Craig, pp. 78-82, National Science Foundation, Washington, D. C., 1982.

Takahashi, T., D. Chipman, and T. Volk, Geographical, seasonal and secular variations of the partial pressure of $\mathrm{CO}_{2}$ in surface waters of the North Atlantic Ocean: The results of the North Atlantic TTO Program, Proceedings Carbon Dioxide Research Conference: Carbon Dioxide, Science and Consensus, Rep. CONF-820970, pp. 123-146, U.S. Dep. of Energy, Washington, D. C., 1983.

Whitfield, $\mathrm{M}$., Accumulation of fossil $\mathrm{CO}_{2}$ in the atmosphere and in the sea, Nature London, 247, 523-525, 1974.

Zimen, K. E., and F. K. Altenhein, The future burden of industrial $\mathrm{CO}_{2}$ on the atmosphere and the oceans, $Z$. Naturforsch. $A, 28$, $1747-1753,1973$

J. G. Acker, P. R. Betzer, and R. H. Byrne, Department of Marine Science, University of South Florida, St. Petersburg, FL 33701.

R. A. Feely and J. F. Gendron, Pacific Marine Environmental Laboratory, NOAA, U.S. Department of Commerce, 7600 Sand Point Way, N. E., Seattle, WA 98115.

(Received September 15, 1983; accepted October 31,1983 .) 